\title{
Pengaruh Keragaman Dewan Direksi, Komisaris Independen dan Konsentrasi Kepemilikan Terhadap Inovasi
}

\author{
Kurniawati $^{1}$ \\ Universitas Bunda Mulia \\ kurniawati@bundamulia.ac.id \\ Imora Kamul ${ }^{2}$ \\ Universitas Bunda Mulia \\ imorakamul19@gmail.com \\ Yohanes James Richard ${ }^{3}$ \\ Universitas Bunda Mulia \\ richard_icat19@yahoo.com \\ Prisella Julianti ${ }^{4}$ \\ Universitas Bunda Mulia \\ prisellajulianti@gmail.com
}

\begin{abstract}
Innovation is the key strategy for the company to grow and survive in a dynamic environment. The role of the board of directors as executive committee, the board of commissioners and the concentration of ownership as monitoring committee, are very important in encouraging innovation. This study aims to investigate whether gender, level of education, and age diversity of board directors, proportion of independent commissioner and concentration of ownership enchance innovations in the company. The sample of this study is manufacturing companies listed in the Indonesia Stock Exchange in 2015-2018. Samples are collected by purposive sampling and resulted in 34 companies as the final sample. Data were analyzed using Multiple Regression Analysis for testing hypothesis with significance level 5\%. The statistical tool used is SPSS 22. The results of this study show that gender diversity and level of education of board directors has positive effect on innovation. However, age diversity has no effect on innovation. In the monitoring function, concentration of ownership has effect on innovation but there is no effect from proportion of independent commissioner.
\end{abstract}

\section{Keywords : board director diversity, independence commissioner, concentration of ownership, innovation}

ABSTRAK
Inovasi merupakan strategi kunci bagi perusahaan untuk bertumbuh dan bertahan dalam lingkungan yang dinamis. Peranan dewan direksi sebagai komite eksekutif serta dewan komisaris dan konsentrasi kepemilikan sebagai komite pengawasan, adalah sangat penting dalam mendorong terciptanya inovasi. Penelitian ini bertujuan untuk menginvestigasi apakah gender, tingkat pendidikan, dan keragaman usia dari dewan direksi serta proporsi komisaris independen dan konsentrasi kepemilikan dapat meningkatkan inovasi dalam suatu perusahaan. Sampel dari penelitian ini adalah perusahaan manufaktur yang terdaftar di Bursa Efek Indonesia tahun 20150-2018. Pemilihan sampel menggunakan teknik purposive sampling dan menghasilkan 34 (tiga puluh empat) perusahaan sebagai sampel akhir. Data dianalisis dengan menggunakan regresi linear berganda untuk menguji hipotesis pada tingkat signifikansi 5\%. Alat statistik yang digunakan adalah SPSS 22. Hasil penelitian menunjukkan bahwa keragaman gender dan tingkat pendidikan dari dewan direksi memiliki pengaruh positif terhadap inovasi. Akan tetapi, keragaman usia tidak berpengaruh terhadap inovasi. Dalam kaitannya dengan fungsi pengawasan, konsentrasi kepemilikan memiliki pengaruh 
terhadap inovasi, akan tetapi proporsi dewan komisaris tidak berpengaruh terhadap inovasi.

Kata Kunci : keragaman dewan direksi, komisaris independen, konsentrasi kepemilikan, inovasi

\section{PENDAHULUAN}

Dalam lingkungan yang penuh dengan persaingan, perkembangan teknologi yang sangat cepat dan perubahaan kebutuhan pelanggan yang hampir pasti terjadi, perusahaan membutuhkan inovasi baik melalui eksploitasi atas pengetahuan yang ada saat ini maupun memperbaharui pengetahuan - pengetahuan serta mengeksplorasi kesempatankesempatan baru (Levinthal dan March, 1993 dalam Rejeb et al., 2019). Perusahaan yang tidak berinovasi lambat laun akan mengalami kemunduran bahkan tidak mungkin akan mengalami kebangkrutan, sebagai contoh Eastman Kodak. Kebangkrutan perusahaan Eastman Kodak disebabkan oleh kelambatannya dalam memperbaharui pengetahuan dan menyebabkan kehilangan kapasitas strategik perusahaan (Ermine, 2003 dalam Rejeb et al., 2019). Inovasi merupakan sumber utama untuk bertahan hidup, daya saing dan kinerja organisasi (Berraies dan Bchini, 2019; Zuraik dan Kelly, 2018 dalam Rejeb et al., 2019). Beberapa negara yang menyadari akan pentingnya inovasi, telah mengeluarkan kebijakan terkait inovasi, seperti yang dilakukan oleh pemerintah Malaysia sejak tahun 1990-an diantaranya Science to Action Initiative and Third National Science, Technology and Innovation Policy. Adanya kebijakan - kebijakan tersebut mendorong perusahaan perusahaan di Malaysia membudayakan inovasi dalam perusahaan mereka yang nantinya diharapkan dapat memberikan kekayaan bagi perusahaan dan negara (Ariff et al., 2017).

Dewan direksi merupakan salah satu elemen kunci dalam tata kelola perusahaan dan juga elemen sentral dari strategi perusahaan yang memegang peranan penting dalam menginisiasi dan mengorganisasi suatu proyek inovasi (Rejeb et al., 2019). Oleh karena itu diperlukan keragaman dewan direksi agar pengambilan keputusan dapat lebih efektif. Keragaman tersebut juga dapat meningkatkan kinerja yang lebih baik seperti dengan adanya ide-ide yang kreatif dan inovatif, serta pemecahan masalah yang baik (Van Knippenberg et al., 2004 dalam Schneid, 2016). Østergaard et al. (2011), menyatakan bahwa keragaman diantara anggota tim direksi cenderung akan menumbuhkan pengetahuan dasar bagi perusahaan dan mendorong interaksi antara berbagai pengetahuan dan kompetensi yang berbeda beda. Anggota dewan haruslah diwakili oleh 
orang - orang yang berkualifikasi tinggi untuk dapat mengambil keputusan strategik yang berguna bagi perusahaan, pemegang saham dan juga negara secara keseluruhan. Berdasarkan data statistik dari Singapore Board Diversity Report 2014 (Dieleman et al., dalam Ariff et al., 2017) menunjukkan bahwa Finlandia menduduki posisi kedua sedangkan Swedia menduduki posisi ketiga atas negara yang memiliki perwakilan wanita terbanyak di jajaran dewan. Sedangkan untuk negara Malaysia, berdasarkan ranking yang dilakukan oleh GII, menunjukkan bahwa perwakilan wanita dalam jajaran dewan masih rendah. Dari data statistik terkait inovasi dan perwakilan wanita di jajaran dewan, di ketiga negara tersebut dapat memberikan pemikiran awal bahwa terhadap hubungan antara keragaman dewan, dalam hal ini gender, dengan ranking negara dalam bidang inovasi.

Selain karakteristik - karakteristik Dewan, keberadaan komisaris independen dan juga kepemilikan memegang peranan penting dalam menunjang adanya inovasi. Keberadaan komisaris independen diharapkan dapat mengawasi dan membantu Chief Executive Officcer (CEO) dalam penetapan strategi, mengurangi agency cost dan menawarkan special expertise untuk membantu dalam pengambilan keputusan atas diversifikasi investasi dan untuk menilai risiko-risiko yang terkandung di dalamnya, hal ini lah yang dinamakan proyek inovasi ( $\mathrm{Wu}$ and $\mathrm{Wu}, 2014)$. Pemilihan komisaris independen dapat menjadi faktor kunci untuk meningkatkan kinerja dewan direksi dalam mencapai inovasi. Komisaris independen akan mencegah CEO menyalahgunakan kekuasaannya terkait alokasi sumber daya untuk inovasi dan tujuan jangka panjang (Wong et al., 2017). Ada kecenderungan CEO melakukan manajemen laba riil dengan cara memotong biaya - biaya terkait penelitian dan pengembangan untuk kepentingan jangka pendek, yaitu untuk mencapai target bonus.

\section{LANDASAN TEORI \& PERUMUSAN HIPOTESIS}

\section{Inovasi}

Inovasi merupakan suatu proses yang dilakukan secara berulang dan melalui berbagai tahapan yang mengubah ide-ide menjadi produk, jasa maupun proses yang membawa perbaikan maupun perubahan baru ke dalam suatu organisasi (Baregheh et al., 2009; Utterback, 1971; Wong et al., 2017 dalam Rajeb et al., 2019). OECD dalam Ariff et al., 2017 mendefinisikan inovasi sebagai sesuatu yang tidak hanya berkaitan dengan 
penelitian dan pengembangan (R\&D), akan tetapi dapat dilihat ke dalam 4 (empat) kategori yaitu: inovasi produk, proses, pemasaran dan organisasi. Inovasi juga dapat diklasifikasikan berdasarkan intensitas dan bergantung pada keinginan perusahaan apakah perusahaan ingin mengeksploitasi pengetahuan yang ada saat ini atau mengeksplorasi sesuatu hal yang baru. Inovasi eksploitatif adalah inovasi tambahan dan mengacu pada proses peningkatan produk dan proses melalui penyempurnaan pengetahuan dan kompetensi yang ada untuk melayani pelanggan yang sudah ada dan pasar (Berraies dan Hamouda, 2018; Li et al., 2010 dalam Rejeb et al., 2019). Inovasi eksplorasi mencerminkan perubahan radikal dalam produk, layanan atau proses, yang merupakan buah dari eksplorasi keterampilan dan pengetahuan baru untuk memenuhi pelanggan yang muncul dan kebutuhan pasar (Benner dan Tushman, 2003; Berraies dan Hamouda, 2018 dalam Rejeb et al., 2019). Sebagian besar literatur berfokus pada dua metode untuk mengukur inovasi, yaitu pertimbangkan input (segala upaya yang dilakukan oleh perusahaan untuk menjadi lebih kompetitif dan lebih inovatif, yang biasanya direpresentasikan oleh pengeluaran untuk penelitian dan pengembangan (R\&D) sebagai persentase dari total penjualan perusahaan, atau dengan jumlah orang terlibat dalam kegiatan penelitian dan pengembangan sebagai persentase dari total karyawan perusahaan) dan hasilnya (hasil dari kegiatan inovatif diukur sebagai jumlah paten terdaftar atau masuk proses terdaftar oleh perusahaan).

\section{Perumusan Hipotesis}

\section{Keragaman Gender Dewan Direksi dan Inovasi}

Beberapa studi menunjukkan bahwa keragaman gender meningkatkan komunikasi, koordinasi, kohesion dan dukungan mutual dalam suatu tim. Anggotaanggota dalam suatu grup/kelompok dipengaruhi oleh pola pikir dan kepribadian masing - masing individu (Diaz-García et al., 2013). Byrne and Worthy (2015) menunjukkan bahwa adanya perbedaan gaya pengambilan keputusan, dimana pria cenderung lebih global, selektif dalam memproses informasi, dan menunjukkan bias kognitif dalam pengambilan keputusan jangka panjang sedangkan wanita cenderung lebih detail, memproses informasi secara menyeluruh dan memiliki kemampuan untuk memaksimalkan baik itu keuntungan jangka menengah maupun jangka panjang. Berdasarkan pemikiran tersebut maka wanita akan lebih mendukung inovasi yang bersifat 
eksploitasi dan eksplorasi. Selain itu terkait cara memproses informasi, keberadaan wanita dalam dewan direksi dapat mengelola pemikiran - pemikiran yang berbeda secara efektif dan menciptakan suasana kolaborasi yang mendorong komunikasi yang lebih terbuka di antara anggota dewan (Bear et al., 2010). Beberapa penelitian terkait keragaman gender pernah dilakukan oleh beberapa peneliti, salah satunya adalah penelitian yang dilakukan oleh Rejeb et al., 2019 menunjukkan bahwa gender dewan memperkuat hubungan peranannya dalam melayani terhadap inovasi. Penelitian Zona et $a l ., 2013$ juga menunjukkan bahwa keragaman gender mendorong terciptanya inovasi yang lebih banyak lagi. Berdasarkan uraian di atas maka hipotesis pertama yang diajukan adalah sebagai berikut:

Ha1: Keragaman gender dewan direksi berpengaruh positif signifikan terhadap inovasi.

\section{Keragaman Tingkat Pendidikan Dewan Direksi dan Inovasi}

Tingkat/Jenjang pendidikan dari sisi literatur manajemen dipandang sebagai suatu pengukuran terhadap pengetahuan individu, keterampilan serta kemampuan kognitif. Menurut Hambrick, et al. (2001) dalam Tarus dan Aime (2014), dengan adanya keragaman tingkat pendidikan yang dimiliki jajaran manajemen level atas akan sangat bermanfaat dalam memberikan keragaman kontribusi serta ide-ide untuk mengambil keputusan dalam rangka perubahan strategi perusahaan demi tercapainya tujuan perusahaan. Perspektif yang berbeda - beda dari latar belakang pendidikan yang berbeda akan membantu meningkatkan kualitas dari proses pengambilan keputusan (Alesina dan La Ferrara 2005 dalam Bolli et al., 2017). Misalnya, mengembangkan prototipe baru menjadi inovasi yang dapat dipasarkan. Ini tidak hanya membutuhkan pandangan dan keahlian ilmiah, tetapi juga kompetensi profesional, pengalaman kerja, dan keterampilan lunak terakhir dalam berbagai bidang ilmu. Parrotta, Pozzoli, dan Pytlikova (2014) dalam Bolli et al., 2017 menunjukkan bahwa keragaman pendidikan mempengaruhi kecenderungan paten atau intensitas paten yang dibuat perusahaan. McGuirk dan Jordan (2012) dalam Bolli et al.,2017 meneliti instrumen keragaman pendidikan di berbagai perusahaan Irlandia dan menemukan bahwa keragaman pendidikan meningkatkan kecenderungan untuk memperkenalkan produk baru tetapi tidak kecenderungan untuk memperkenalkan proses baru. Berdasarkan uraian tersebut maka hipotesis kedua yang diajukan adalah sebagai berikut: 
Ha2: Keragaman tingkat pendidikan dewan direksi berpengaruh positif signifikan terhadap inovasi

\section{Keragaman Usia Dewan Direksi dan Inovasi}

Keragaman usia telah menjadi suatu tolak ukur terhadap kinerja suatu perusahaan. Pada usia yang berbeda, kemampuan berpikir, cara pandang, kemampuan teknologi akan berbeda. Perusahaan yang memiliki komposisi usia dewan direksi yang beragam, akan memiliki kemampuan yang lebih, variasi ide yang baru serta dapat mengikuti perkembangan zaman. Akibat tuntutan perkembangan yang begitu pesat, diperlukan anggota dewan yang berasal dari berbagai kelompok usia (Mishra dan Jhunjhunwala, 2013). Dengan adanya keragaman usia maka akan ada sudut pandang yang berbeda sehingga dapat meningkatkan kualitas operasi bisnis. Dewan direksi juga menjadi pendamping CEO dalam mengatur risiko inovasi dan memberikan kewenangan atas proyek inovasi (Boyd, 1990 dalam Rejeb et al., 2019). Inovasi tersebut akan menjadi tanggung jawab dan keputusan dari dewan direksi. Latar belakang dewan direksi menjadi salah satu faktor kunci dalam inovasi (Rejeb et al., 2019). Penelitian yang dilakukan oleh Hammermann et al., 2019 menunjukkan bahwa age diversity berpengaruh terhadap inovasi. Berdasarkan uraian tersebut maka hipotesis ketiga yang diajukan adalah sebagai berikut:

Ha3 : Keragaman usia dewan direksi berpengaruh positif signifikan terhadap inovasi

\section{Komisaris Independen dan Inovasi}

Keberadaan komisaris independen di struktur organisasi suatu perusahaan dalam rangka menciptakan tata kelola perusahaan yang baik memberi dampak positif terhadap perusahaan, karena komisaris independen dapat memberikan pengawasan yang kuat terhadap manajemen untuk tujuan peningkatan kinerja perusahaan. Menurut Peraturan Otoritas Jasa Keuangan (POJK) nomor 33 /POJK.04/2014 Pasal 20 mensyaratkan bahwa minimal jumlah dewan komisaris yang dimiliki oleh suatu perusahaan adalah 2 (dua) orang, dan satu diantaranya adalah komisaris independen. Menurut Kusumastuti (2006) dalam Dewi dan Dewi (2016) dewan komisaris dengan proporsi komisaris independen yang cukup kuat akan memiliki perilaku pengawasan manajerial. Diharapkan dengan semakin banyaknya keterwakilan komisaris independen dalam dewan komisaris dapat meningkatkan efektivitas monitoring terhadap upaya - upaya untuk memotong biaya - 
biaya yang memiliki manfaat jangka panjang seperti biaya riset dan pengembangan serta biaya - biaya lain yang terkait dengan terciptanya suatu inovasi. Penelitian yang dilakukan oleh Zona et al., 2013 menunjukkan bahwa komisaris independen berpengaruh positif signifikan terhadap inovasi. Berdasarkan uraian tersebut maka hipotesis keempat yang diajukan adalah sebagai berikut:

\section{Ha4: Komisaris independen berpengaruh positif signifikan terhadap inovasi}

\section{Konsentrasi Kepemilikan dan Inovasi}

Kepemilikan yang terkonsentrasi dapat meningkatkan pengawasan dengan lebih efektif karena dapat memiliki kekuatan/insentif lebih besar. Sebaliknya jika kepemilikan tersebar, maka setiap pemegang saham memiliki sedikit insentif dalam mengawasi manajemen karena lebih besar cost dibandingkan benefit-nya Menurut (Alchian and Demsetz 1972; Jensen and Meckling 19 dalam Shapiro et al, 2015). Akibatnya kepemilikan yang tersebar memungkinkan manajer untuk terlibat dalam kegiatan selain inovasi yang lebih berisiko, sedangkan kepemilikan terkonsentrasi akan lebih mendukung aktivitas inovasi Hill and Snell 1988; Baysinger, Kosnik, and Turk 1991 dalam Shapiro et al, 2015). Selain itu konsentrasi kepemilikan mendorong komitmen karena tidak mudah bagi pemegang saham mayoritas untuk keluar dari perusahaan (Mayer, 1997 dalam Shapiro et al, 2015). Akibatnya, pemegang saham mayoritas akan terlibat dalam proyek - proyek jangka panjang dan proyek - proyek yang terkait dengan R \& D. Akan tetapi hubungan konsentrasi kepemilikan dengan inovasi cenderung tidak liniear (Lee, 2005 dalam Shapiro et al, 2015). Meskipun konsentrasi memberikan insentif kepada pemegang saham terbesar untuk komit terhadap aktivitas-aktivitas jangka panjang yang menguntungkan, diantaranya adalah inovasi, akan tetapi pada titik tertentu, jika kepemilikan tersebut ditambah lagi, justru pengawasan yang efektif sulit terealisasi. Menurut penelitian Omri et al. (2014), perusahaan dengan kepemilikan terkonsentrasi, pemegang saham mayoritas memiliki leadership role dalam mengontrol manajemen yang akhirnya dapat mengurangi konflik keagenan antara pemegang saham dan manajemen serta dapat mengurangi agency costs terkait kegiatan inovasi dengan mendorong manajemen untuk menerapkan ide-ide inovasi kreatif dalam perusahaan (Omri et al., 2014). Berdasarkan uraian tersebut maka hipotesis kelima adalah sebagai berikut:

Ha5: Konsentrasi kepemilikan berpengaruh signifikan terhadap inovasi 


\section{METODE PENELITIAN}

\section{Populasi dan Sampel}

Populasi dalam penelitian ini adalah perusahaan manufaktur yang terdaftar di Bursa Efek Indonesia periode 2015-2018. Pemilihan sampel dalam penelitian ini menggunakan teknik purposive sampling, dan setelah memenuhi kriteria dan membuang outlier maka diperoleh 34 (tiga puluh empat) perusahaan sebagai sampel akhir.

\section{Jenis Penelitian \& Operasional Variabel}

Jenis penelitian yang digunakan penelitian ini adalah penelitian kuantitatif. Data yang diperlukan dalam penelitian ini merupakan data sekunder yang diperoleh dari laporan keuangan tahunan yang telah diaudit atas perusahaan manufaktur periode 20152018 yang berasal dari www.idx.co.id. Berikut ini adalah pengukuran variabel operasional yang digunakan dalam penelitian ini:

\section{Variabel Dependen}

\section{Inovasi (INV)}

Inovasi merupakan suatu proses yang menterjemahkan ide-ide menjadi suatu produk, jasa maupun proses yang membawa perbaikan maupun perubahan baru ke dalam suatu organisasi. Inovasi dapat dalam bentuk eksplorasi maupun eksploitasi. Investasi baik eksplorasi maupun eksploitasi membutuhkan biaya. Dalam akuntansi, biaya terkait eksplorasi dan eksploitasi dapat dikategorikan sebagai biaya riset dan pengembangan. Dalam tahapan riset semua biaya dibebankan ke dalam Research \& Development cost. Sedangkan untuk tahap pengembangan ada yang masih sebagai beban dan ada yang dapat dikapitalisasikan sebagai aset (intangible asset). Menurut Ariff, 2017, terdapat 2 (dua) dimensi dalam pengukuran inovasi, yaitu intangible asset dan research \& development cost. Dalam penelitian ini, pengukuran inovasi lebih melihat yang sudah memiliki kelayakan ekonomi (economic viabilitiy), sehingga layak dikapitalisasikan. Untuk itu rumus pengukuran inovasi yang digunakan dalam penelitian ini adalah yang digunakan oleh Rogers (1998) dalam Ariff, 2017 sebagai berikut :

\section{Inovasi $=$ Intangible Assets $/$ Total Assets}

\section{Variabel Independen}

a. Keragaman gender 
Untuk variabel keragaman gender yang diklasifikasikan ke dalam 2 (dua) kategori yaitu: (1) laki - laki dan (2) perempuan, dan diukur dengan menggunakan Herfindahl Index. Nilai H berada diantara $0-1$, dewan direksi (Tarus \& Aime, 2014)

b. Keragaman latar belakang tingkat pendidikan diklasifikasikan dalam lima kategori yaitu: (1) Tidak ada gelar, (2) Diploma, (3) Sarjana, (4) Master, dan (5) Doktor (Tarus \& Aime, 2014), dan diukur dengan menggunakan Herfindahl Index.

c. Keragaman usia diukur dengan menggunakan Covarian dari umur setiap dewan direksi (Tarus \& Aime, 2014)

d. Komisaris Independen diukur dengan menggunakan proporsi komisaris independen yaitu jumlah komisaris independen dibagi dengan total dewan komisaris (Shapiro et al., 2015)

e. Konsentrasi Kepemilikan, diukur dengan menggunakan jumlah persentase pemegang saham terbesar (Shapiro et al., 2015)

\section{Metode Analisis Data}

Teknik analisis yang digunakan adalah dengan melakukan pengujian hipotesis dengan menggunakan analisis regresi linear berganda. Berikut ini adalah model persamaan regresi yang digunakan dalam penelitian ini:

$$
\text { INV }=\alpha+\beta_{1} \text { GEN }+\beta_{2} \text { EDU }+\beta_{3} \mathrm{AGE}+\beta_{4} \mathrm{KI}+\beta_{5} \mathrm{CONCENTRATE}+\varepsilon
$$

\section{Keterangan:}

$\begin{array}{ll}\text { INV } & =\text { Inovasi } \\ \text { GEN } & =\text { Keragaman Gender Dewan Direksi } \\ \text { EDU } & =\text { Keragaman tingkat pendidikan Dewan Direksi } \\ \text { AGE } & =\text { Keragaman usia Dewan Direksi } \\ \text { KI } & =\text { Proporsi Komisaris Independen } \\ \text { Concentrate } & =\text { Konsentrasi kepemilikan } \\ \alpha & =\text { Konstanta regresi } \\ \beta_{1} \beta_{2} \beta_{3} \beta_{4} \beta_{5} & =\text { Koefisien regresi } \\ \varepsilon & =\text { Error }\end{array}$

\section{Hasil dan Pembahasan}

\section{Statistik Deskriptif}


Berdasarkan tabel statistik deskriptif di bawah ini, dapat terlihat bahwa nilai rata - rata gender dewan direksi menunjukkan angka 0,1159 yang berarti variasi keberadaan gender wanita dalam struktur dewan direksi atas perusahaan sampel sangatlah minim dibawah angka 1 (satu). Sedangkan untuk rata - rata keragaman tingkat pendidikan sedikit lebih tinggi dari keragaman gender, yaitu sebesar 0,3884. Namun demikian angka ini tetap masih dibawah 1, yang artinya komposisi tingkat pendidikan dewan komisaris dan dewan direksi masih belum banyak tersebar. Di kategori usia, nilai rata - rata keragaman usia dewan direksi yang diukur dengan covarian adalah 0,1266 . Sedangkan untuk komposisi usia dewan direksi masih didominasi di usia 50 tahun ke atas. Nilai rata - rata persentase komisaris independen adalah sebesar $41,72 \%$. Hal ini menunjukkan bahwa tingkat kepatuhan para emiten terhadap aturan OJK telah sangat baik. Nilai ratarata konsentrasi kepemilikan adalah $64,92 \%$, hal ini berarti rata - rata tingkat kepemilikan saham terbesar atas perusahaan sampel adalah cukup karena sudah melebihi 50\%. Nilai rata - rata inovasi adalah sebesar 1,25\%. Hal ini berarti proporsi intangible assets sebagai proksi dari inovasi masih tergolong sangat kecil dibandingkan total aset yang dimiliki. Saat ini, perusahaan - perusahaan sampel masih banyak memiliki aset tetap dibandingkan aset takberwujud (intangible assets).

\section{Tabel 1}

\section{Statistik Deskriptif}

\begin{tabular}{lllll} 
Variabel & Average & Std.Dev & Minimum & Maksimum \\
\hline GEN & 0.1159 & 0.16316 & 0.00 & 0.50 \\
EDU & 0.3884 & 0.20967 & 0.00 & 0.66 \\
AGE & 0.1266 & 0.07153 & 0.01 & 0.44 \\
KI & 0.4172 & 0.15478 & 0.00 & 1.00 \\
CONCENTRATE & 0.6492 & 0.24335 & 0.10 & 1.00 \\
INV & 0.0125 & 0.01769 & 0.00 & 0.08
\end{tabular}

Sumber : Hasil olahan data peneliti dengan menggunakan SPSS 22

\section{Hasil Uji dan Interpretasi}

Berikut adalah tabel yang menunjukkan hasil regresi berganda atas model penelitian:

Tabel 2

\section{Hasil Uji Regresi}

\begin{tabular}{ccccc} 
& Expected Sign & Koefisien & Sig & \\
\hline Constant & & 0,010 & 0,154 & \\
GEN & + & 0,020 & 0,032 & $* *$
\end{tabular}




\begin{tabular}{ccccc} 
EDU & + & 0,017 & 0,022 & $* *$ \\
AGE & + & 0,014 & 0,506 & \\
KI & + & 0,008 & 0,405 & $* * *$ \\
$\begin{array}{c}\text { CONCENTRAT } \\
\text { E }\end{array}$ & $+/-$ & $-0,018$ & 0,004 & \\
\hline \multicolumn{4}{r}{$\mathrm{R}^{2}=0.119$} \\
& Prob $<\mathrm{F}=0,005$ & \\
& \multirow{4}{*}{,$* * * *$ signifikan pada $\alpha=10 \%, 5 \%, 1 \%$}
\end{tabular}

\section{Interpretasi Hasil}

\section{Pengaruh keragaman gender dewan direksi terhadap inovasi}

Berdasarkan hasil pengolahan data menunjukkan bahwa nilai sig. Gender Dewan Direksi $=0.032<$ tingkat signifikansi $\alpha=5 \%$, dan nilai koefisien gender menunjukkan hasil positif sebesar 0.020 , sehingga hipotesis $\mathrm{Ha}_{1}$ diterima yang berarti gender dewan direksi memiliki pengaruh signifikan dan berhubungan positif terhadap inovasi. Hasil pengujian ini membuktikan beberapa pandangan yang menyatakan bahwa keragaman gender dewan direksi memberikan keuntungan bagi perusahaan dalam hal berinovasi. Hal ini disebabkan dengan adanya perbedaan cara berpikir serta psikologis antara pria dan wanita dapat lebih meningkatkan kreativitas, inovasi, pemecahan masalah serta pengambilan keputusan yang lebih efektif. Dengan adanya direksi wanita diharapkan rencana inovasi akan dipikirkan lebih matang tetapi juga harus tepat dan cepat dalam mengambil keputusan dalam berinovasi (kecepatan dan keberanian dalam mengambil keputusan biasanya didominasi oleh direksi pria). Selain itu juga, perpaduan antara keunggulan wanita dalam hal estetika serta kemampuan direksi pria dalam meng-update kemajuan teknologi akan membawa dampak yang sangat baik dalam menciptakan inovasi - inovasi yang unggul.

\section{Pengaruh keragaman tingkat pendidikan dewan direksi terhadap inovasi}

Berdasarkan hasil pengolahan data menunjukkan bahwa nilai sig. tingkat pendidikan Dewan Direksi $=0.022<$ tingkat signifikansi $\alpha=5 \%$, sehingga hipotesis $\mathrm{Ha}_{2}$ diterima Hal ini berarti tingkat pendidikan dewan direksi memiliki pengaruh signifikan terhadap inovasi. Koefisien tingkat pendidikan dewan direksi menunjukkan hasil yang positif yaitu 0.017. Hal ini berarti secara arah hubungan, keragaman tingkat pendidikan dewan direksi dapat meningkatkan terjadinya inovasi. Hasil pengujian ini membuktikan bahwa dengan 
adanya kolaborasi dari tingkat pendidikan yang berbeda dapat membantu mengidentifikasi hal - hal baru yang muncul dari kegiatan penelitian perusahaan dan pada saat yang sama perusahaan akan lebih dapat ide-ide atau teknologi baru yang menjanjikan. Perspektif yang berbeda - beda dari tingkat pendidikan yang berbeda akan membantu meningkatkan kualitas dari proses pengambilan keputusan (Alesina dan La Ferrara 2005 dalam Bolli et al., 2017). Misalnya, mengembangkan prototype baru menjadi inovasi yang dapat dipasarkan. Ini tidak hanya membutuhkan pandangan dan keahlian ilmiah, tetapi juga kompetensi profesional, pengalaman kerja, dan keterampilan lunak terakhir dalam berbagai bidang ilmu.

\section{Pengaruh Keragaman Usia Dewan Direksi terhadap Inovasi}

Berdasarkan hasil pengolahan data, menunjukkan bahwa nilai sig.keragaman usia Dewan Direksi $=0.506>$ tingkat signifikansi $\alpha=5 \%$, sehingga hipotesis $\mathrm{Ha}_{3}$ ditolak. Hal ini berarti keragaman usia dewan direksi tidak berpengaruh signifikan terhadap inovasi. Koefisien keragaman usia menunjukkan hasil yang positif yaitu 0.014. Hasil pengujian ini membuktikan bahwa dengan adanya keragaman usia dewan direksi akan meningkatkan terjadinya inovasi. Namun demikian, hubungan yang positif ini tidak terbukti secara empiris memiliki pengaruh yang signifikan. Adapun yang menyebabkan hal ini terjadi adalah bauran keragaman usia memang dapat memunculkan ide-ide inovatif dari para direksi yang berusia muda, namun perlu disadari keberadaan dewan direksi yang lebih berumur dan lebih "senior" mungkin akan berusaha menghalangi dilakukannya inovasi tersebut jika dirasa inovasi tersebut tidak memiliki tingkat kepastian yang tinggi akan mengalami kesuksesan dalam pemasarannya nanti. Dalam beberapa perusahaan tingkat senioritas juga masih tetap dijunjung tinggi, dan bukan tidak mungkin pendapat dari senior ini yang lebih didengarkan.

\section{Pengaruh Proporsi Komisaris Independen terhadap Inovasi}

Berdasarkan hasil pengolahan data, menunjukkan bahwa nilai sig. proporsi komisaris independen $=0.405>$ tingkat signifikansi $\alpha=5 \%$, sehingga hipotesis $\mathrm{Ha}_{4}$ ditolak. Hal ini berarti proporsi komisaris independen tidak memiliki pengaruh signifikan terhadap inovasi. Koefisien proporsi komisaris independen menunjukkan hasil yang positif yaitu 0.008. Hal ini berarti secara arah hubungan, semakin tinggi proporsi komisaris 
independen dapat meningkatkan inovasi. Hasil pengujian ini menunjukkan bahwa jumlah banyak sedikitnya komisaris independen tidak bisa dapat dijadikan acuan bahwa akan mempengaruhi dilakukannya inovasi. Jika keberadaan jumlah komisaris independen tersebut masih bersifat homogen dan umumnya didominasi oleh usia yang sudah cukup lanjut, maka inovasi tidaklah mudah dilakukan

\section{Pengaruh Konsentrasi Kepemilikan terhadap Inovasi}

Berdasarkan hasil pengolahan data, menunjukkan bahwa nilai sig. konsentrasi kepemilikan $=0.004<$ tingkat signifikansi $\alpha=5 \%$, sehingga hipotesis Has ditolak. Hal ini berarti konsentrasi kepemilikan memiliki pengaruh signifikan terhadap inovasi. Koefisien konsentrasi kepemilikan menunjukkan hasil yang negatif yaitu -0.018 . Hal ini berarti secara arah hubungan, semakin tinggi persentase kepemilikan dari pemegang saham mayoritas justru dapat menurunkan inovasi. Hasil pengujian sesuai dengan pendapat yang dikemukkan oleh Shapiro et al, 2015, bahwa meskipun konsentrasi memberikan insentif kepada pemegang saham terbesar untuk komit terhadap aktivitas-aktivitas jangka panjang yang menguntungkan, diantaranya adalah inovasi, akan tetapi pada titik tertentu, jika kepemilikan tersebut ditambah lagi, justru pengawasan yang efektif sulit terealisasi.

\section{KESIMPULAN}

Dari hasil penelitian, dapat disimpulkan bahwa dari variabel keragaman dari sisi gender dan latar belakang tingkat pendidikan dewan direksi menunjukkan hasil yang sesuai dengan hipotesis yang diajukan sedangkan untuk keragaman usia belum terbukti secara empiris memberikan pengaruh yang signifikan. Dari sisi mekanisme pengawasan yaitu dewan komisaris belum dapat memberikan pengaruh yang signifikan terhadap dilakukannnya inovasi, sedangkan konsentrasi kepemilikan yang diukur dari persentase saham terbesar, mampu menunjukkan pengaruh yang signifikan terhadap inovasi. Hanya saja, jika persentase kepemilikan terbesar melebihi batas tertentu, justru dapat menurunkan inovasi.

Dari hasil penelitian, dapat disarankan bahwa untuk membuat suatu kebijakan yang mendorong terciptanya keragaman dalam dewan direksi, terutama dalam hal keragaman gender maupun tingkat pendidikan yang telah terbukti secara empiris memberikan pengaruh dalam mendorong terciptanya inovasi. Dari sisi pengawasan 
diharapkan berhati - hati dalam menentukan batasan kepemilikan saham terbesar karena hal ini justru akan berpotensi menurunkan inovasi jika batasan tersebut terlampaui. Beberapa keterbatasan penelitian seperti hanya melihat peranan komisaris independen dari sisi jumlah saja menjadi keterbatasan penelitian ini, yang mungkin menjadi penyebab belum sesuainya hasil dengan hipotesis yang diajukan. Untuk itu di penelitian selanjutnya diharapkan menggunakan proksi lainnya seperti efektivitas kinerja dewan komisaris.

\section{DAFTAR PUSTAKA}

Ariff, AM., Salleh, Z., Noor, MNHM., Mohamad, NR., and Ismail, N. 2017. Board diversity and innovation performance in Malaysia. Int. J. Business Governance and Ethics, Vol. 12(3), pp. 241-261.

Bear, S., Rahman, N., and Post, C. 2010. The impact of board diversity and gender composition on corporate social responsibility and firm reputation. Journal of Business Ethics, Vol. 97(2), pp. 207-221.

Bolli, Thomas., Renold, Ursula., and Worter, Martin. 2017. Vertical education diversity and innovation performance. Economics of Innovation and Technology, Vol. 27(2).

Byrne, K., and Worthy D. 2015. Gender differences in rewards sensitivity and information processing during decision-making. Journal of Risk Uncertainty, Vol.50 (1), pp. 55-71.

Dewi, LGK., and Dewi, A. A. 2016. Pengaruh diversitas dewan komisaris dan direksi pada perusahaan sektor keuangan yang terdaftar di Bursa Efek Indonesia Tahun 2009-2013. E-Jurnal Akuntansi Universitas Udayana, Vol.16 (1), Hal.812-836.

Diaz-Garcia C., Gonzales-Moreno, A., and Saez-Martinez, F.J. 2013. Gender diversity within R\&D teams: Its impact on radicalness of innovation. Management, Policy \& Practice, Vol 15(2), 149-160.

Hammermann A., Niendorf, M., Schmidt J. 2019. Age Diversity and Innovation: Do mixed teams of 'old and experienced' and 'young and restless' employees foster companies' innovativeness? IAB Discussion Papper. The research institute of the German Federal Employment Agency

Mishra, R. K., and Jhunjhunwala, S. 2013. Diversity and the Effective Corporate Board. Academic Press, pp 75-85.

Omri, W., Becuwe, A., and Mathe, JC. 2014. Ownership structure and innovative behavior. Journal of Accounting in Emerging Economies, 4(2), 220-239. 
Østergaard, C.R., Timmermans, B. and Kristinsson, K. 2011. Does a different view create something new? The effect of employee diversity on innovation. Research Policy, Vol. 40 (3), pp. 500-509.

Rejeb, WB., Berraies, S., and Talbi, D. 2019. The contribution of board of directors' roles to ambidextrous innovation: Do board's gender diversity and independence matter? European Journal of Innovation Management, Vol 23 (1), pp 40-66.

Schneid, Matthias., Isidor, Rodrigo., Steinmetz, Holger., Kabst Rudiger. 2016. Age diversity and team outcomes: a quantitative review Journal of Managerial Psychology, 31 (1), pp. 2-17.

Shapiro, D., Tang, Y., Wang, M. and Zhang, W. 2015. The effects of corporate governance and ownership on the innovation performance of Chinese SMEs. Journal of Chinese Economic and Business Studies, Vol. 13 (4), pp. 311-335.

Tarus, D K., and Aime, F. 2014. Board demographic diversity, firm performance and strategic change: A test of moderation. Management Research Review. Vol 37(12). pp 1110-1136.

Wong, Y.-J., Lee, C.-Y. and Chang, S.C. 2017. CEO overconfidence and ambidextrous innovation. Journal of Leadership \& Organizational Studies, Vol. 24(3), pp. 414430.

$\mathrm{Wu}, \mathrm{J}$. and $\mathrm{Wu}, \mathrm{Z}$.2014. Integrated risk management and product innovation in China: the moderating role of board of directors. Technovation, Vol. 34 (8), pp. 466-476.

Zona, F., Zattoni, A. and Minichilli, A. 2013. A contingency model of boards of directors and firm innovation: the moderating role of firm size. British Journal of Management, Vol. 24 No. 3,pp. 299-315. 